\title{
AVOINTA JA MODULAARISTA: KOHA SAAPUI TIETEELLISIIN KIRJASTOIHIN
}

Kun päätös Koha-kirjastojärjestelmän valinnasta syntyi, tärkeä valintakriteeri oli se, että avoimen lähdekoodin ohjelmiston nähtiin soveltuvan parhaiten modulaariseen järjestelmäkehitykseen. Koha-kirjastot katsoivat, että kirjastot ja kirjastoteknologia ovat kypsiä aidosti modulaarisen teknisen ympäristön rakentamiseen. Koha-järjestelmän käyttöönottoa korkeakouluissa auttoi yleisissä kirjastoissa aiemmin tehty työ. Tiivis yhteistyö ja yhdessä tekeminen on kehittämisen avain jatkossakin, niin kansallisesti kuin kansainvälisesti. Tulevaisuuden suuria kehityskohteita ovat e-aineistojen hallintaan (ERM) ja kuvailuun liittyvät ratkaisut.

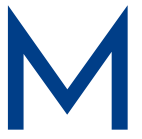

aaliskuussa 2018 kuusitoista kirjastoa päätti siirtyä pitkään palvelleesta Voyagerkirjastojärjelmästä Kohaan ${ }^{1}$. Kun Hämeen ammattikorkeakoulun kirjasto ensimmäisenä otti Kohan käyttöön lokakuussa $2018^{2}$, oli hetki historiallinen. Voyager-järjestelmästä irtautuminen Suomessa oli totta, ja korkeakoulujen pitkä kirjastojärjestelmäyhteistyö haarautumassa kahtaanne. Nyt keväällä 202 I olemme näiden järjestelmien osalta jo melko lailla tottuneet uusiin olosuhteisin. Taivas ei pudonnut niskaamme.

\section{Valinta tuli äkkiä eteen}

Korkeakoulukirjastojen polku Voyager-kirjastojärjestelmän seuraajan valinnassa oli ollut pitkä ja polveileva. Helmikuun alussa 2018 oltiin nopeasti eteen tulleen valintatilanteen edessä, kun 12 korkeakoulukirjastoa ja yksi erikoiskirjasto ilmoittivat eroavansa yhteisestä sopimuspohjaisesta hankin- taprosessista. Päätösten teolle ei siinä vaiheessa jäänyt paljon aikaa. Vaihtoehtoja oli käytännössä kaksi: lähteäkö eroajien mukaan kilpailuttamaan kaupallista järjestelmää; vai ottaako käyttöön avoimen lähdekoodin Koha-kirjastojärjestelmä yhteistyössä muiden kirjastojen kanssa.

Ajatus Koha-kirjastojärjestelmän käyttöönotosta ei avoimen koodin järjestelmää kannattavien kirjastojen keskuudessa syntynyt tyhjästä. Aiemmassa avoimeen koodiin tähdänneessä Uusi kirjastojärjestelmä -hankkeessa (UKJ) Koha oli tosin todettu riittämättömäksi hankkeen tavoitteisiin nähden. Hanke kuitenkin seurasi Joensuun seutukirjaston etenemistä sen omassa Koha-projektissa. uKJ:n kariuduttua Jyväskylän yliopiston kirjasto alkoi keväällä 20 I 5 tutkia tarkemmin Kohan soveltuvuutta korkeakoulukirjaston tarpeisiin ${ }^{3}$. Puutteita löytyi, mutta kypsyi myös käsitys, että Kohan kanssa voisi elää - varsinkin järjestelmän kehittyessä. Kansalliskir- 
jasto pystytti Koha-järjestelmän vielä yhteishankinnan puitteissa testausta varten syksyllä 20I7. Testausta tekivät Kansalliskirjaston asiantuntijat, ja muutkin saattoivat siihen osallistua.

Mitkä seikat vaikuttivat valintaan? Kohaan siirtyneiden kirjastojen kesken ei ole yhdessä käyty tarkasti läpi organisaatioiden valintaperusteita. Eri kirjastoilla oli luonnollisesti eri näkökulmia. Esillä keskusteluissa oli muun muassa halu hyödyntää mahdollisimman pitkälle kansallisia, окм:n rahoittamia kansallisia infrastruktuureja. Samoin avoimen lähdekoodin mahdollisuudet houkuttivat. Vaikka avoimen lähdekoodin muokkaaminen ei ole täysin vailla rajoitteita, kuten alempana selostetaan, tarjoaa se kuitenkin suoremmat mahdollisuudet vaikuttaa kehittämisen suuntaan ja priorisointeihin. Myös kustannukset näyttelivät osaansa.

Lisäksi vaihtoehdot erosivat toisistaan merkittävästi yhteistyömallin osalta. Kilpailuttava ryhmä lähti siitä, että yhdessä tehtäisiin vain kilpailutus; sen jälkeen kaikki jatkaisivat järjestelmän käyttäjinä toisistaan riippumattomina. Koha-ryhmä taas lähti ensisijaisesti rakentamaan yhteistyötä ja yhdessä tekemistä kirjastojärjestelmän ylläpitoon ja kehittämiseen liittyvissä asioissa.

\section{Modulaarisuus oli jo totta}

Suuri merkitys oli sillä, että avoimen lähdekoodin ohjelmiston katsottiin varmimmin soveltuvan modulaariseen kokonaisuuteen. Modulaarisuudesta on tullut integroitavuuden jälkeen jär- jestelmämarkkinoiden avainsana. Jos kirjaston järjestelmäympäristö koostuu yhteentoimivista mutta erillisistä komponenteista, voi ajatella esimerkiksi niiden vaihtamista yksi kerrallaan. Se tietenkin vähentää sellaisia tuskia, joita koko järjestelmän kerralla vaihtaminen todistetusti aiheuttaa. Mutta modulaarisuudella on asteensa: kokemus on raadollisesti osoittanut, että kunkin kaupallisen järjestelmätoimittajan moduuleilla on taipumus toimia hyvin vain toistensa kanssa.

Koha-ratkaisu on alusta asti ja tietoisesti nojannut vahvasti modulaarisiin kansallisiin palveluihin ja niiden parissa tapahtuvaan yhteistyöhön. Ensinnäkin, Koha-kirjastojen jatkoivat kuvailemista suoraan Melindaan, kansalliseen metatietovarantoon. Se on tietenkin keventänyt merkittävästi Kohan kuvailutyökaluihin kohdistuvaa kehittämispainetta. Toiseksi, kaikki tieteelliset Koha-kirjastot ovat alusta asti käyttäneet Finnaa asiakkaiden ainoana käyttöliittymänä kokoelmaluetteloon sekä varauksien ja uusintojen tekemiseen. E-aineistojen hallinnan ratkaisu, jota eräissä Koha-kirjastoissa paraikaa pohditaan, voidaan sekin toteuttaa omana moduulinaan.

Tässä moduulien maailmassa kirjastojärjestelmä on suorastaan värä sana kuvaamaan Kohaa. Finna ja Melinda, nekin vielä omine moduuleineen, ovat yhtä lailla osa kirjaston informaatioteknologista selkärankaa.

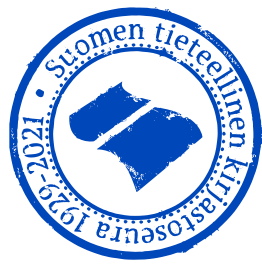


Avoimen lähdekoodin vapaus ja vastuu

voimen lähdekoodin parissa on kirjastoissa työskennelty jo vuosia. Julkaisuarkisto-ohjelmisto DSpace oli yksi tienraivaajista, ja kansallinen hakupalvelu Finna on keskeinen avoimeen lähdekoodiin perustuva palvelu. (Näitä molempia muuten yhdistää se, että avoimen lähdekoodin ratkaisuun päädyttiin tilanteessa, jossa kaupallisen, suljetun tuotteen kanssa aloitettu kehittäminen juuttui ylitsepääsemättömiin vaikeuksiin.)

Yksi perusteista avoimen lähdekoodin käytölle on "vapaus muokata ohjelmistoa haluamakseen" ${ }^{4}$. Vapaa muokkaaminen on tosiaankin mahdollista, mutta ei aivan ongelmatonta varsinkaan pidemmällä aikajänteellä. Koha on maailmanlaajuisesti suosittu ohjelmisto, ja sillä on laaja kehittäjäkunta ja vilkas käyttäjäyhteisö. Koska lähdekoodi on avointa, sitä voi muokata mieleisekseen, kun siihen on halua, taitoa ja aikaa. Muokkaaminen luo siitä muunnoksen, joka ei ole enää täsmälleen se Koha, jonka koko muu maailma tuntee. Kun niin kutsuttu yhteisöversio päivittyy, muokkaajankin olisi hyvä ottaa se käyttöön. Etenkin tietoturvan takia vanhat versiot ovat hyvin ongelmallisia, mutta ohjelmisto toki kehittyy muutenkin.

Päivityksen yhteydessä kirjaston olisi siis itse uudestaan räätälöitävä tekemänsä muutokset uuteen versioon. Näin pitää tehdä jok'ikisessä uudessa päivityksessä, ja Kohan päivitys olisi hyvä tehdä ainakin kahdesti vuodessa. Kevyet muutokset on kenties mahdollista ympätä mukaan aina uudestaan, mutta mitä lukuisampia, suurempia ja syvällisempiä muutokset ovat, sitä työläämmiksi päivitykset käyvät. Voi käydä niinkin, että Kohan koodi muuttuu tavalla, joka pakottaa kirjoittamaan omia piirteitä pitkälti uusiksi.

Kaikenlainen muokkaus on siis mahdollista, mutta ei ilman jatkuvaa kustannusta. Joskus kustannukset ovat puolustettavissa ja hyödyt niin ilmeisiä, että haarasta voi syntyä suorastaan erillinen tuote - tämäkään ei ole ohjelmistomaailmassa harvinaista.

Voisiko kirjasto sitten saada tekemänsä muutokset mukaan Kohan yhteisöversioon? Kyllä voi, ja tästä avoimen lähdekoodin ohjelmistokehityksessä onkin kysymys: käyttäjät kehittävät ohjelmistoa yhteistuumin. Mitä merkittävämpi ja suositumpi tuote, sitä enemmän sillä on kehittäjiä, eikä muutosten tekeminen voi olla villiä ja vapaata. Kohan kehittämiselle on sovittu täsmälliset menettelytavat, jotka pakostakin hillitsevät kehittämisen vapautta. Ehdotettavien muutosten tulee olla sellaisia, että yhteisö pitää niitä mielekkäinä, tai ainakaan ne eivät saa häiritä niitä, joita muutos ei kiinnosta. Ne tulee myös toteuttaa laadukkaalla ja kestävällä tavalla, eivätkä ne tavat aina ole nopeimpia ja helpoimpia. Esimerkiksi Suomen tieteellisten Koha-kirjastojen ehdotus Kohan lainaussääntöjen toimintatavan muuttamiseksi ei ole oikein saavutta- 
nut vastakaikua yhteisössä. Näin ollen täytyy pohtia, miten haluttu lopputulos saavutetaan toisella tavalla.

Jonkinlaisen välimuodon kehittämisessä muodostavat lisäosat eli pluginit. Ne ovat erillisiä ohjelmistoja, jotka kytkeytyvät pääjärjestelmään sen rajapintojen kautta, koodiin kajoamatta. Rajapinnatkin voivat muuttua, mutta muutosten hallinta on huomattavasti yksinkertaisempaa. Toisaalta lisäosilla ei voida toteuttaa aivan kaikkea.

\section{Kansallisesta kansainväliseen Koha-versioon}

$\mathrm{K}$ ohaan siirtyvät Voyager-kirjastot päättivät ottaa pohjaksi Suomen yleisissä kirjastoissa käytössä olevan Kohan version. Joensuun seutukirjasto oli aloittanut 20 I I projektin, jonka tarkoituksena oli selvittää avoimen lähdekoodin kirjastojärjestelmien soveltuvuutta ${ }^{5}$. Selvitys johti lopulta Kohan käyttöönottoon vuonna 20 I 4 ja pian kaikissa Vaara-kirjastoissa ${ }^{6}$. Ratkaisu herätti välittömästi mielenkiintoa muuallakin, niin että nopealla tahdilla myös Lumme- ja Outi-kirjastot valitsivat Kohan. Kirjastokimppojen yhteistyö syveni ja keskittyi 2016 perustetun voittoa tuottamattoman Koha-Suomi Oy:n ympärille.

Yleisissä kirjastoissa Kohaan oli tehty lukuisia suomalaisten kirjastojen käytäntöjä tukevia muutoksia. Ilman tätä versiota ja yleisten kirjastojen piirissä karttunutta Koha-osaamista ei sen käyttöönotto tieteellisellä puolella olisi mitenkään voinut käydä niin nopeasti ja sujuvasti kuin se kävi.

Kansallisen kehitystyön käytössä on kuitenkin myös varjopuolensa. Edellä kuvatuista syistä Koha-version päivittäminen yhteisöversion uusiin versioihin oli käynyt työlääksi ${ }^{7}$. Näytti lisäksi siltä, että korkeakoulu- ja erikoiskirjastoissa kansallisten muokkausten merkitys ei ollut niin kriittinen kuin yleisissä kirjastoissa. Siksi, kohta käyttöönottojen sarjan päätyttyä, ne päättivät siirtyä Kohan yhteisöversioon ${ }^{8}$. Keväällä 2020 päätettiin kriittisistä kehitysasioista, joihin yhteisöversiossa oli saatava aikaan muutoksia. Kevät ja kesä keskityttiin niiden toteuttamiseen. Päivityskierros alkoi elokuussa 2020 ja päättyi tammikuussa $202 \mathrm{I}$.

Yhteisöversioon siirtymisen myötä taakse jäi myös suurten ja vaikeiden, päivän kestävien päivitysrupeamien kausi, ja voitiin siirtyä useammin tapahtuviin mutta käyttäjien kannalta huomattavasti kevyempiin päivityksiin.

\section{Kehittäminen on kansallista ja kansainvälistä yhteistyötä}

Kohan käyttöönottoon lähteneille kirjastoille oli alusta alkaen selvää, että tiivistä yhteistyötä tehdään sekä käyttöönotto- että tuotantovaiheessa. Myös laajempi, kansallinen ja kansainvälinen yhteistyö on ollut monipuolista. Tämä on osoittautunut hyväksi ratkaisuksi. Käyttäjäyhteisö on enemmän kuin osiensa summa.

Paperilla voi näyttää siltä, että Kansalliskirjasto ja csc tuottavat kehittämis- ja ylläpitopalveluita joukolle 
käyttäjiä. Niin ei suinkaan ole! Kirjastot eivät ole passiivisia asiakkaita, vaan niiden asiantuntemus ja sen jatkuva jakaminen ovat palvelun aivan keskeisiä osatekijöitä. Kirjastoissa työskentelevien ymmärrys järjestelmän toiminnasta eri tilanteissa, asetusten vaikutuksista, paikallisten laitteiden ja sovellusten integroimisesta ja monista muista seikoista täydentää koodaajien ja ylläpitäjien osaamista. Jatkuva dialogi lisää osaamista puolin ja toisin?

Kansainvälisessä Koha-yhteistyössä on tärkeää olla mukana myös niin sanoaksemme yhteisrintamana. Järjestelmän parissa kohtaavat erilaiset käytännön tarpeet ja suorastaan erilaiset kirjastokulttuurit. On ollut tarpeen rummuttaa sitä seikkaa, että Suomessa on merkittävän suuri Kohan käyttäjäkunta, jossa on mukana varsin suuria ja vilkkaasti käytettyjä kirjastoja - sen ääntä olisi siis syytä kuulla ${ }^{10}$. Asiaa on auttanut se, että Suomessa on nyt kaksi kehittäjäorganisaatiota, Kansalliskirjasto ja Koha-Suomi Oy, jotka voivat tukea toisiaan kehittämisehdotusten läpiviennin prosesseissa ${ }^{11}$. Koha-yhteisössä verkostot ja henkilökohtaiset kontaktit ovat yhtä tärkeitä kuin millä tahansa kansainvälisellä foorumilla.

Suomen yleisten kirjastojen Koha-osaaminen hyödytti suuresti tieteellisiä kirjastoja monenlaisen yhteistyön ja tuen muodossa. Myös tuo yhteistyö on jatkunut. Kehitystehtävien hallinta tapahtuu yhteisessä tikettijärjestelmässä. Pääkäyttäjät ja asiantuntijat vierailevat toistensa tapaamisissa, ja myös johtotasolla yhteydenpito on säännöllistä. Vuodesta 20 I 8 lähtien on järjestetty myös yhteisiä tapaamisia ja webinaareja.

Olemme edenneet hyvän matkaa modulaarisuuden tiellä. Koha-yhteenliittymän kirjastoille on tärkeää eri ratkaisujen yhteentoimivuus sekä vapaus osallistua itselle tärkeiden toiminnallisuuksien kehittämiseen että olla osallistumatta jonkin toiseen kehittämishankkeeseen ja sen rahoitukseen. Tästä on esimerkkinä e-aineistojen hallinta (ERM, electronic resources management). Sen tukea ei vielä ole Kohassa eikä ehkä koskaan tulekaan. Mutta e-aineistojen hallintaa voidaankin ajatella jälleen yhtenä moduulina. Koha-yhteenliittymän kirjastoista viisi on ilmoittanut olevansa tässä vaiheessa kiinnostuneita ERM:istä. Ne ovat aloittaneet Folio ERM:iin tutustumisen testiasennuksin. Aika tulee näyttämään, onko se seuraava avoimen lähdekoodin osa yhteenliittymän kirjastojen ohjelmistopaletissa.

\section{Luovasta kaaoksesta keveisiin rakenteisiin}

Koha-yhteistyön alkaessa maaliskuussa 20 I 8 oli hyvin selvää, että Voyager-kirjastojärjestelmän ylläpitosopimukset sekä ExLibriksen että csc:n kanssa tullaan irtisanomaan I. I. 2020 alkaen. Kirjastojärjestelmien vaihdot piti saada käyntiin mahdollisimman pian, jotta kaikki ehdittäisiin tehdä ennen vuoden 2019 loppua. Yhteistyö käynnistyi tiiviillä yhteisellä tekemisellä. 


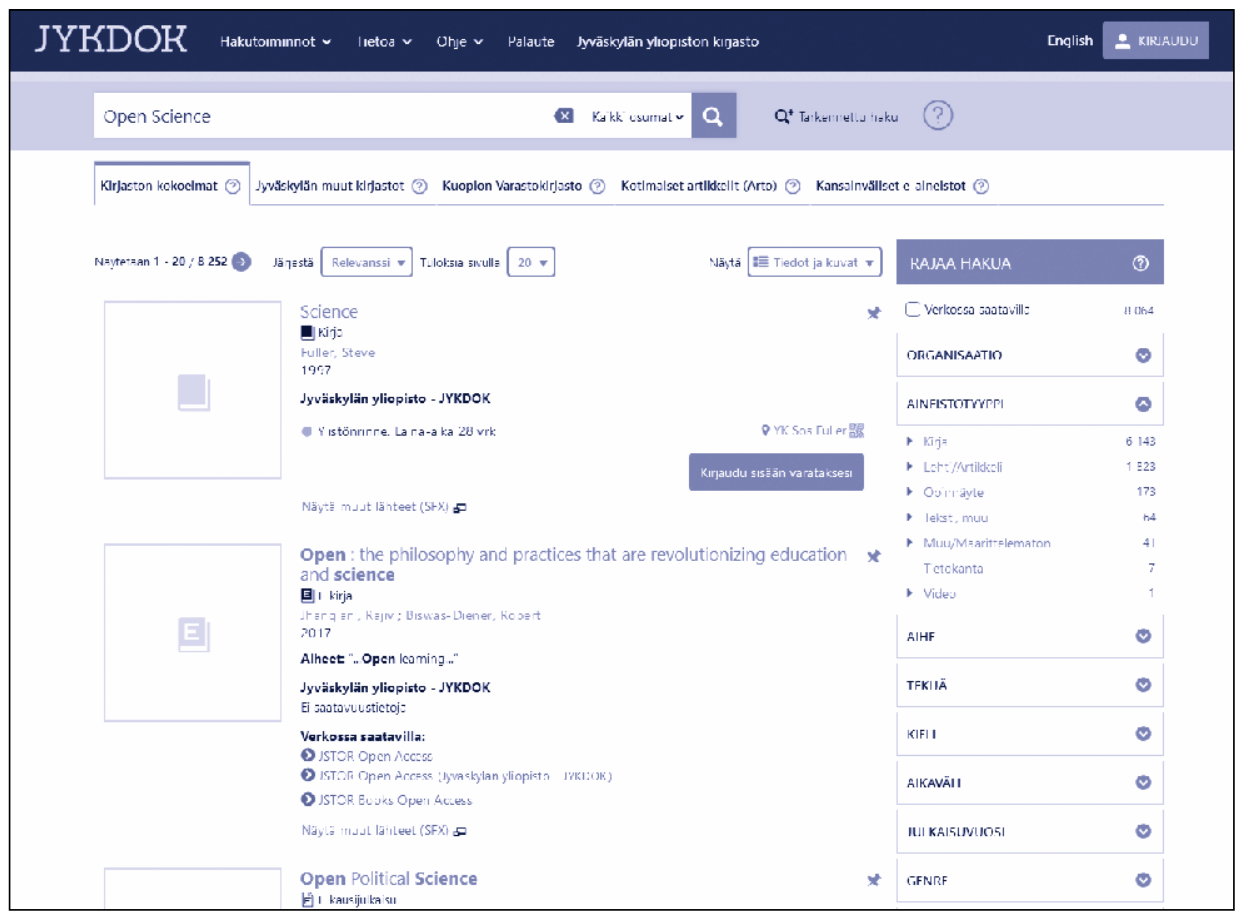

Koha on käytössä mm. Jyväskylän yliopistossa, jossa yliopistokirjasto alkoi keväällä 2015 tutkia Kohan soveltuvuutta korkeakoulukirjaston tarpeisiin.

Kirjastot eivät jääneet pohtimaan yhteisen henkilöstön palkkaamista eikä kustannustenjakomalleja. Työt tehtiin talkoohengessä yhteiseksi hyväksi keskinäisen luottamuksen varassa Yhteistyön tarkempia pelisääntöjä alettiin valmistelemaan vasta ensimmäisten käyttöönottojen jälkeen.

Korkeakoulut tilaavat Kohan ylläpidon csc:ltä. Sopimusteknisesti se on vain yksi liite lisää korkeakoulun ja CSC:n väliseen puitesopimukseen. Koha-ylläpidon liitteessä on todettu tilaajien muodostavan yhteenliittymän, joka huolehtii tilaajien yhteisestä tahdonmuodostuksesta niissä asioissa, joissa se on tarpeen palvelun toteuttamiseksi. Kansalliskirjasto toimii teknisesti csc:n alihankkijana, ja vas- taa Kohan ylläpidosta ja kehityksestä yhteenliittymän osalta. Csc huolehtii palvelinympäristöstä.

Korkeakoulu- ja erikoiskirjastojen Koha-yhteistyö perustuu siis verraten kevyesti organisoidulle yhteenliittymälle. Heti käyttöönottovaiheen aluksi todettiin, että kyseessä on vapaa yhteenliittymä, joka toimii yhdessä sovittavien pelisääntöjen mukaisesti. Koha-järjestelmällä ei katsottu olevan erillistä omistajaa, vaan käytöstä, ylläpidosta ja kehittämisestä sovitaan yhdessä yleiskokouksessa ${ }^{12}$. Nopean käyttöönottovaiheen aikana työnjaosta sovittiin joustavasti. Myös CsC palveluntarjoajana kantoi kortensa kekoon siinä, että kaikki kirjastot saivat Kohan käyttöön 3 I. I 2. 20 I9 mennessä. Käyttöönotto- 
vaiheen jälkeen siirryttiin Kohan ylläpidossa ja kehittämisessä varsinaisesti sopimuspohjaiseen toimintaan.

Yhteenliittymällä on yleiskokous ja ohjausryhmä. Näiden lisäksi keskeisiä ovat pääkäyttäjäverkosto ja asiantuntijaryhmä; tässä on otettu mallia yleisten Koha-kirjastojen järjestäytymisestä. Pääkäyttäjät keskustelevat jatkuvasti käytännön kysymyksistä: miten saada aikaan tietynlainen toiminto, mistä jokin havaittu ongelma johtuu jne. Asiantuntijaryhmä hallinnoi virheilmoituksia ja kehittämisehdotuksia ja tekee ohjausryhmälle esityksiä kehittämisasioista.

Mainittakoon, että Kansalliskirjasto ei ole yhteenliittymän jäsen. Tämä on selkeämpää sen ollessa myös palveluntarjoaja. Se osallistuu kuitenkin aktiivisesti pääkäyttäjäverkoston ja asiantuntijaryhmän toimintaan, missä myös kehittäjät ovat kuulolla. Kansalliskirjaston ja CsC:n edustajat ovat yleensä asiantuntijoina mukana myös ohjausryhmässä ja yhteenliittymän kokouksissa. CsC:n ja Kansalliskirjaston tarjoamaa Koha-palvelua tarkastellaan lisäksi säännönmukaisissa laatupalave- reissa Koha-yhteenliittymän kirjastojen edustajien kanssa, nykyään kolmesti vuodessa.

\section{Onnistumisen iloa}

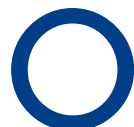
lemme vakuuttuneita siitä, että kirjastot ja kirjastoteknologia ovat kypsiä aidosti modulaarisen teknisen ympäristön rakentamiseen. Voidaan väittää, ettei yhden toimittajan ratkaisuihin sitoutumisella olisi saavutettavissa ratkaisevaa lisäarvoa, niin kuin ei pitäisikään olla. Nykyisellä ratkaisulla voidaan mainiosti toimia nähtävillä olevassa tulevaisuudessa. Tulevaisuuden suuria kysymyksiä on, paitsi tarpeellisten ERM-ratkaisujen tekeminen, kuvailussa häämöttävien suurten muutosten aiheuttamat vaatimukset järjestelmien kehittämiselle.

Kirjastoille Kohan käyttöönotto on ollut kokemuksena jännittävä - sanan kaikissa merkityksissä. Kiirettä ja epävarmuutta on ollut, virheitä havaittu ja tehty itse; mutta sitäkin enemmän on saatu myönteisiä kokemuksia yhteistyön, avoimuuden ja luottamuksen voimasta.

\section{Kirjoittajat}

\author{
Ari Ahlqvist \\ Kansalliskirjasto \\ ari.ahlqvist@helsinki.fi
}

SinikKa LuOKKANEN

Hämeen ammattikorkeakoulu sinikka.luokkanen@hamk.fi
Esa-Pekka Keskitalo

Kansalliskirjasto esa-pekka.keskitalo@helsinki.fi

\author{
Ari Muhonen \\ Itä-Suomen yliopisto \\ ari.muhonen@uef.fi
}




\section{Viitteet:}

1 Lisäksi seitsemästoista, Maanpuolustuskorkeakoulu, teki päätöksen Kohaan siirtymisestä myöhemmin.

2 Hämeen ammattikorkeakoulu 20I8. HAMK julistaa uuden Koha-kirjastojärjestelmän käyttöönottoa. Arkistoitu 28.4. 202I. https://web.archive.org/web/202 I042808 I944/ https://www.hamk.fi/20I8/hamk-juhlistaa-uuden-koha-kirjastojarjestelmankayttoonottoa/

3 Lassila Matti, Markkanen Hannu, Häkkinen Veli-Matti,

Koha-kirjastojärjestelmän testaus Jyväskylän yliopiston kirjastossa.

Luettu 4. 5. 202I. https://jyx.jyu.fi/handle/I $23456789 / 47836$

4 Tonteri, Petri 20 I2: Joensuun avoin kirjasto. Kirjastolehti I 5. I 2. 20 I2. Luettu 28.4. 202 I. <http://kirjastolehti.fi/artikkelit/joensuun-avoin-kirjasto/>

5 Avoin kirjasto 2013. Arkistoitu 25.9.20 I I. Luettu 28.4. 202 I. <https://web.archive. org/web/20 I 407052 I 4050/https://wiki.kirjastot.fi/index.php?title=Avoin_kirjasto_20 I 3>

6 Joensuun seutukirjasto siirtyi avoimen koodin kirjastojärjestelmään. 20 I4? Luettu 28. 4. 202 I. <https://www.kirjastot.fi/tiedotteet/joensuun-seutukirjasto-siirtyi-avoimenkoodin-kirjastojärjestelmään-ad8694>

7 Mäkiranta, Ari 2020. Kohan versioiden historiaa ja tulevaisuutta. Koha-webinaari 2. 10. 2020. Videotallenne, 2:55-27:I 5 . Katsottu 28.4.2021. <http://urn.fi/URN:NBN:fife2020I0238760I>

8 Koha-yhteenliittymän kokous I/2020. Pöytäkirja I I. 2. 2020. Viimeksi muokattu I 8. 2. 2020. Luettu 3. 5. 2021. <https://www.kiwi.f/ $/ \mathrm{x} / \mathrm{KgA} 7 \mathrm{CQ}>$

9 Työryhmistä, tapahtumista yms. on runsaasti tietoa avoimesti saatavilla Kohayhteenliittymän sivuilla, https://www.kiwi.fi/display/KK

10 Vuoden 2020 Kohacon-konferenssissa pidettiin juuri tästä näkökulmasta kaksi esitystä: (I) Mäkirjanta, Ari \& Keskitalo, Esa-Pekka: Unique Koha Cooperation. Videotallenne: https://youtu.be/AWYFvgml_bU ; ja (2) Pilppula, Rebekka: World's Best Libraries. Videotallenne: https://youtu.be/bkEl2 2 bw $50 \mathrm{M}$

11 Hyvin suuri painoarvo Koha-yhteisössä on niillä kaupallisilla toimijoilla, jotka tarjoavat Kohaan perustuvia järjestelmäpalveluita. Esimerkiksi ByWater Solutionsilla on asiakkaanaan tuhatkunta kirjastoa. <https://librarytechnology.org/product/koha-bywater> 12 Koha-ryhmän alustavan ohjausryhmän kokous 23.3.20I8. <https://www.kiwi.fi/pages/ viewpage.action?pageId=93192722 > 